\title{
2 可変パラメータによる多慣性負荷系の制振制御
}

$\begin{array}{llllll}\text { 正員 } & \text { 船 } & \text { 渡 } & \text { 寛 } & \text { (宇都宮大学) } \\ \text { 正員 } & \text { 山 } & \text { 本 } & \text { 磿 } & \text { (キャ)ン株式会社) } \\ \text { 学生員 } & \text { 原 } & & \text { 賢 } & \text { 志 } & \text { (宇都宮大学) } \\ \text { 正員 } & \text { 橋 } & \text { 本 } & \text { 誠 } & \text { 司 (宇都宮大学) } \\ \text { 正員 } & \text { 神 山 } & \text { 健 三 } & \text { (宇都宮大学) }\end{array}$

Vibration Suppression Control using Two Variable Parameters in a Multi-Mass System

Hirohito Funato, Member (Utsunomiya University), Kiyohito Yamamoto, Member (Canon Inc.), Kenji

Hara, Student Member, Seiji Hashimoto, Member, Kenzo Kamiyama, Member (Utsunomiya University)

The torsional vibration is often initiated by the momentary impact which occurs when a load is connected to a motor by several mechanical coupling parts. An industrial servo system is basically represented as a multi-mass system. To suppress the vibration generated in the two-mass load, many control methods have been developed for practical use. In this paper, however, the authors propose a simple vibration suppression strategy for the multi-mass system which employs two variable parameters consisting of resonance ratio and damping factor along with a state feedback approach. The excellent vibration suppression control, as an example, for a three-mass system, resulting in excellent vibration suppression even for a small resonant ratio, is verified by simulations and experiments.

キーワード：多慣性負荷系, 軸ねじれ振動, 振動抑制, 状態フィードバック, 2 可変パラメータ

\section{1. まえがき}

サーボ系の課題の一つに軸ねじれ振動がある(1)。2慣性 負荷系の軸ねじれ振動については，共振比制御，モデル追 従制御，状態フィードバックなどの手法が提案され，害用化 されている(1)〜 (6)。しかし，多慣性負荷系に対しては，現 在のところ, 塞用的な手法が少ないようである。3慣性負 荷系については，久保氏の状態フィードバックを用いた制 振制御の報告がある(5)。

ここでは，多慣性負荷系の制振制御に共通的に適用でき る実用的な手法を提案する。筆者らは，以前報告した 2 慣 性負荷系に対寸る 2 可変パラメー夕による制振制御 (8)を多 慣性負荷系へ適用拡大する可能性について, シミュレーショ

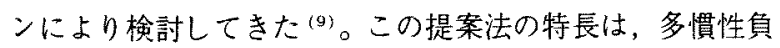
荷系に状態フィードバックを施し，各振動モードを剛体系 に近づければ, 速度制御器を $P I$ 補償のような簡単な補償 にできる点にある。従って，振動抑制制御系とは独立に速 度サーボ系の目標值応答特性を速度制御器によって設定で きる。また, 状態推定オブザーバによりトルク外乱も推定 できるので，それにより外乱応答特性の改善も可能である。 さらに, 慣性比が 1 以下の場合でも，目標值応答時とトル
ク外乱応答時の軸ねじれ振動抑制にも有効である。前回の シミュレーションの結果 (9)を今回実験により検証できたの で, 多慣性負荷系の特徴および 2 慣性負荷系との相違点に つきに総括的に報告する。また，多慣性負荷系の具体的な 例として，実験装置で実現容易な 3 慣性負荷系をとりあげ， その制振制御に対する設計手順につても報告する。

\section{2. 多慣性負荷系}

本論文は，電動機と負荷がギアを介して弾性軸により接

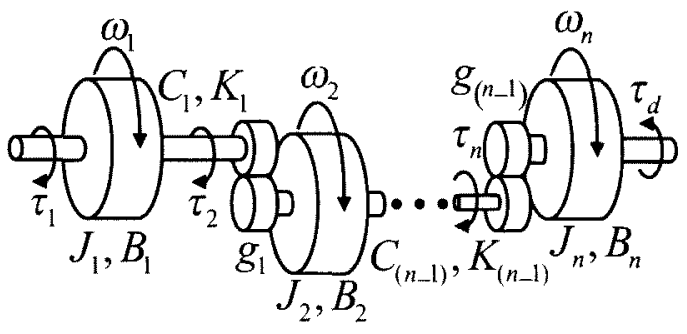

図 1 多慣性負荷系のモデル

Fig. 1. Model of multi-mass plant: 
続された負荷系を制御対象とする。このような負荷系は, 図 1に示すような電動機とギア，負荷がそれぞれ独立した質点 系を構成し，一般に多慣性負荷系となる(1) (5)。

〈2.1〉多慣性負荷系のモデル＼cjkstart多慣性負荷系は数式モ デルとして次のように表せる。

$$
\begin{aligned}
& J_{1} \ddot{\theta}_{1}=-B_{1} \dot{\theta}_{1}-\frac{K_{1}}{g_{1}}\left(\frac{\theta_{1}}{g_{1}}-\theta_{2}\right) \\
& -\frac{C_{1}}{g_{1}}\left(\frac{\dot{\theta}_{1}}{g_{1}}-\dot{\theta}_{2}\right)+\tau_{1} \\
& J_{2} \ddot{\theta}_{2}=K_{1}\left(\frac{\theta_{1}}{g_{1}}-\theta_{2}\right)+C_{1}\left(\frac{\dot{\theta}_{1}}{g_{1}}-\dot{\theta}_{2}\right) \\
& -B_{2} \dot{\theta}_{2}-\frac{K_{2}}{g_{2}}\left(\frac{\theta_{2}}{g_{2}}-\theta_{3}\right) \\
& -\frac{C_{2}}{g_{2}}\left(\frac{\dot{\theta}_{2}}{g_{2}}-\dot{\theta}_{3}\right) \\
& J_{3} \ddot{\theta}_{3}=K_{2}\left(\frac{\theta_{2}}{g_{2}}-\theta_{3}\right)+C_{2}\left(\frac{\dot{\theta}_{2}}{g_{2}}-\dot{\theta}_{3}\right) \\
& -B_{3} \dot{\theta}_{3}-\frac{K_{3}}{g_{3}}\left(\frac{\theta_{3}}{g_{3}}-\theta_{4}\right) \\
& -\frac{C_{3}}{g_{3}}\left(\frac{\dot{\theta}_{3}}{g_{3}}-\dot{\theta}_{4}\right) \\
& J_{n} \ddot{\theta}_{n}=K_{n-1}\left(\frac{\theta_{n-1}}{g_{(n-1)}}-\theta_{n}\right) \\
& +C_{n-1}\left(\frac{\dot{\theta}_{n-1}}{g_{(n-1)}}-\dot{\theta}_{n}\right) \\
& -B_{n} \dot{\theta}_{n}-\tau_{d} \\
& \tau_{1}=k_{h w} i^{*} \\
& \dot{\theta}_{i}=\omega_{i} \\
& \text { ただし， } \\
& \theta_{i}: \text { マスの回転角 } \\
& \omega_{i} \text { : マスの回転速度 } \\
& J_{i} \text { : マスの慣性モーメント } \\
& K_{i}: \text { 軸のバネ定数 } \\
& B_{i} \text { : マスの粘性係数 } \\
& \tau_{1}: \text { 操作卜ル夕 } \\
& C_{i} \text { : 軸粘性係数 } \\
& g_{i}: \text { ギア比 } \\
& \tau_{d} \text { : トルク外乱 } \\
& k_{h w} \text { : 变換係数 } \\
& (i=1,2, \cdots, n)
\end{aligned}
$$

この多慣性負荷系のブロック線図を図 2 に示す。

図 2 において， $i^{*}$ は制御入力としての電流指令を表す。こ こで $\omega_{1} / i^{*}$ は次式となる。

$\frac{\omega_{1}}{i^{*}}=\frac{k_{h w}}{J_{1}} \cdot \frac{1}{s} \cdot \prod_{i=1}^{n-1} \frac{\left(s^{2}+2 \zeta_{a i} \omega_{a i} s+\omega_{a i}^{2}\right)}{\left(s^{2}+2 \zeta_{r i} \omega_{r i} s+\omega_{r i}^{2}\right)}$

ただし，

$\omega_{r i}$ ：共振角周波数 $\omega_{a i}$ : 反共振角周波数

$\zeta_{r i}, \zeta_{a i}:$ 隇衰定数

多慣性負荷系の特徴はその極によって左右され， $\zeta_{r i}$ は非常 に小さくほほ零である。したがって，共振角周波数相当の 振動が生じる。

$\langle 2 \cdot 2\rangle$ 共振角周波数及び反共振角周波数

多慣性負荷系の状態方程式は次式で表される。
$\dot{x}=\mathbf{A} x+\mathbf{B} i^{*}$

ただし， $x$ は状態量であり，

$x=\left[\begin{array}{llllll}\omega_{n} & \tau_{n} & \omega_{n-1} & \cdots & \tau_{2} & \omega_{1}\end{array}\right]^{T}$

また $\mathbf{A} ， \mathbf{B} は$ 行列であり，次式で与えられる。

$$
\begin{gathered}
\mathbf{A}=\left[\begin{array}{ccc}
a_{11} & a_{12} & \cdots \\
a_{21} & a_{22} & \cdots \\
\vdots & \vdots & \\
a_{(2 n-1) 1} & a_{(2 n-1) 2} & \cdots \\
& \cdots & a_{1(2 n-1)} \\
& \cdots & a_{2(2 n-1)} \\
& & \vdots \\
& \cdots & a_{(2 n-1)(2 n-1)}
\end{array}\right] \\
\mathbf{B}((2 n-1) \times 1)=\left[\begin{array}{llll}
0 & \ldots & 0 & \frac{k_{h w}}{J_{1}}
\end{array}\right]^{T}
\end{gathered}
$$

ここで， $\mathbf{A}$ 行列は，奇数行が行列の対角成分とその左右各 1 つの成分（1 行については右成分のみ，(2n-1) 行につい ては左成分のみ，，偶数行が行列の対角成分とそれの左右 各 2 つ成分（2 行については右成分は 1 つ，(2n-2) 行に ついては左成分は $1 つ)$ 加構成されていて，他の要素は 零である。各構成要素は, 奇数行が $(7)$ 式, 偶数行が $(8)$ 式 に示すように表される。

$$
\begin{aligned}
& \left.\begin{array}{l}
a_{(2(n-i)+1)(2(n-i))}=-\frac{1}{g_{i} J_{i}} \\
a_{(2(n-i)+1)(2(n-i)+1)}=-\frac{B_{i}}{J_{i}} \\
a_{(2(n-i)+1)(2(n-i)+2)}=\frac{1}{J_{i}}
\end{array}\right\} \\
& a_{(2(n-i))(2(n-i)-2)}=\frac{C_{(i-1)}}{g_{i} J_{i}} \\
& a_{(2(n-i))(2(n-i)-1)}=\frac{B_{i} C_{(i-1)}}{J_{i}} \\
& -K_{(i-1)} \\
& a_{(2(n-i))(2(n-i))}=-\frac{C_{(i-1)}}{g_{(i-1)}^{2} J_{(i-1)}} \\
& -\frac{C_{(i-1)}}{J_{i}} \\
& a_{(2(n-i))(2(n-i)+1)}=-\frac{B_{(i-1)} C_{(i-1)}}{g_{(i-1)} J_{(i-1)}} \\
& +\frac{K_{(i-1)}}{g_{(i-1)}} \\
& a_{(2(n-i))(2(n-i)+2)}=\frac{C_{(i-1)}}{g_{(i-1)} J_{(i-1)}} \\
& (i=1,2,3, \cdots, n)
\end{aligned}
$$




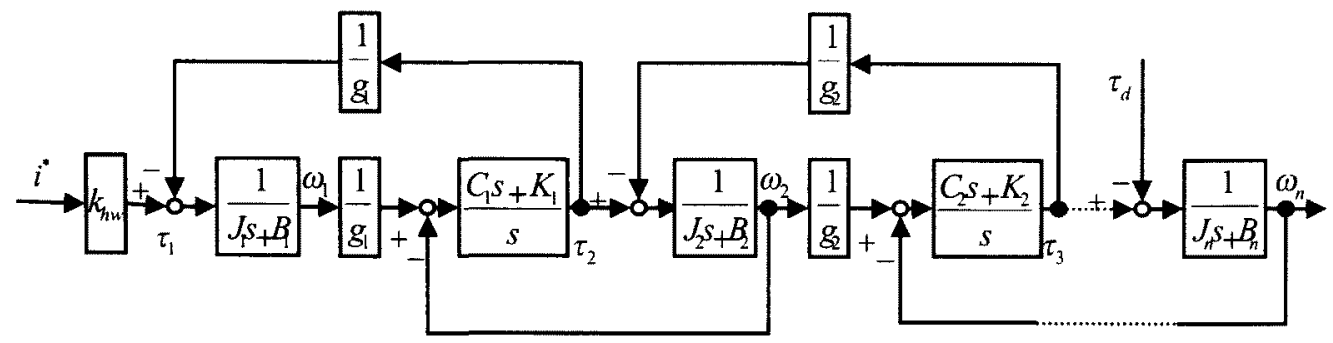

図 2 多慣性負荷系のブロック図

Fig. 2. Block diagram of multi-mass plant.

$y=\mathbf{C} x$

$\mathbf{C}(1 \times(2 n-1))=\left[\begin{array}{lllll}0 & 0 & \cdots & 0 & 1\end{array}\right]$

ここで，システムの極および零点はそれぞれ次式の根で 与えられる。

極: $|s \mathbf{I}-\mathbf{A}|=0$

零点 : $\mathbf{C} \cdot \operatorname{adj}(s \mathbf{I}-\mathbf{A}) \cdot \mathbf{B}=0$

この極，零点より各振動モードの共振角周波数及び反共振 角周波数は導出される。

多慣性負荷系においては，各振動モードの共振角周波数 及び反共振角周波数の解析解を求めることは一般的に困難 であるが，3慣性負荷系の共振角周波数及び反共振角周波 数の解析解について検討する。まず，図 2，(2) 式より伝達 関数 $\omega_{1} / i^{*}$ は次式となる。

$$
\begin{aligned}
\frac{\omega_{1}}{i^{*}}= & \frac{k_{h w}}{J_{1}} \cdot \frac{1}{s} \cdot \frac{\left(s^{2}+2 \zeta_{a 1} \omega_{a 1} s+\omega_{a 1}^{2}\right)}{\left(s^{2}+2 \zeta_{r 1} \omega_{r 1} s+\omega_{r 1}^{2}\right)} \\
& -\frac{\left(s^{2}+2 \zeta_{a 2} \omega_{a 2} s+\omega_{a 2}^{2}\right)}{\left(s^{2}+2 \zeta_{r 2} \omega_{r 2} s+\omega_{r 2}^{2}\right)} \cdots \cdots
\end{aligned}
$$

ここで $B_{1}=B_{2}=B_{3}=0, C_{1}=C_{2}=0$ のとき,

式上り 1 次反共振角周波数 $\omega_{a 1}, 2$ 次反共振角周波数 $\omega_{a 2}$ は 次式となる。

$$
\begin{aligned}
& \omega_{a 1}=\sqrt{\frac{1}{2} \cdot\left(\Omega-\sqrt{\Omega^{2}-\frac{4 K_{1} K_{2}}{J_{2} J_{3}}}\right)} \\
& \omega_{a 2}=\sqrt{\frac{1}{2} \cdot\left(\Omega+\sqrt{\Omega^{2}-\frac{4 K_{1} K_{2}}{J_{2} J_{3}}}\right)}
\end{aligned}
$$

$$
\text { ただし。 }
$$

$\Omega=\frac{K_{1}}{J_{2}}+\frac{K_{2}}{J_{3}}+\frac{K_{2}}{g_{2}^{2} J_{2}}$

上式より，3 慣性負荷系における反共振角周波数は 2 慣 性負荷系の場合 ${ }^{(8)}$ と同様に，慣性モーメント及び軸のバネ 定数によって決定される。

\section{3. 多慣性負荷系の制振制御}

〈3.1〉 2 慣性負荷系との相違点及び制御上の留意点 シ ステムの振動特性はその極によって左右され，(2) 式の共 振角周波数 $\omega_{r i}$ と減衰定数 $\zeta_{r i}$ によって決定される。よって, これらのパラメータを共振比 $R_{i}$, 減衰定数 $\zeta_{r i}$ を用いて調 整することで振動抑制は可能となる。

このような観点から，筆者らは，多慣性負荷系に対しても すでに報告した 2 可変パラメータによる制振制卸法 ${ }^{(8)}\left({ }^{(9)}\right.$ が 適用できるのではないかと，その可能性を 3 慣性負荷系お よび 4 慣性負荷系に対してシミュレーションで検討してい た。ところが多慣性負荷系では共振点が複数個，すなわちn 慣性系では $(\mathrm{n}-1)$ 個あり，隣接する反共振比 $\left(\omega_{a i} / \omega_{a(i-1)}\right)$ はそれぞれ異なる。そのため， $R_{i}$ の設定が適切でないと，

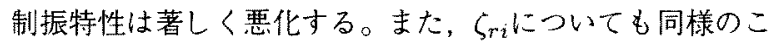
とがいえる。このようなことから， $R_{i} や \zeta_{r i}$ については各振 動モードの周波数特性を念頭に置いて，設定することが重 要であることを確認した。さらに，2慣性負荷系で実現で きた速度制御器の PI 補償, 状態フィードバック係数の設計 からの独立性などは，多慣性負荷系でもそのまま実現でき ることも確認した。シミュレーションでのこのような結果 をふまえて, 次のような 2 可変パラメー夕による多慣性負 荷系の制振制御法を提案する。

〈3・2〉提案する制振制御法提案する多慣性速度制御 系を図 3 に示す。まず，電流指令 $i$ と制御量である電動機 速度 $\omega_{1}$ から状態推定オブザーバ(193)老構成し, 状態量であ る各慣性の速度 $\omega_{i}$, 軸卜ルク $\tau_{i}(i=1,2, \cdots, n)$, を推定す る。次に,これらの推定值を用いて状態フィードバック補 償を施す。図3において, 状態フィードバック補償を施した ときの $\omega_{1} / r$ が次式となるように極を操作する。ここで， $r$ は状態フィードバック補償を施した制御对象への入力とな る。状態フィードバック補償による極配置の方法について は，文献を参照されたい(11)。

$\frac{\omega_{1}}{r}=\frac{k_{h w}}{J_{1}} \cdot \frac{K_{k}}{s} \cdot \prod_{i=1}^{n-1} \frac{\left(s^{2}+2 \zeta_{a i} \omega_{a i} s+\omega_{a i}^{2}\right)}{\left(s^{2}+2 \zeta_{k i} \omega_{k i} s+\omega_{k i}^{2}\right)}$

(17) 式において，Kk $K_{k}$ は共振角周波数の設定にともなうゲ インの変化を調整するための補償定数で次式となる。 


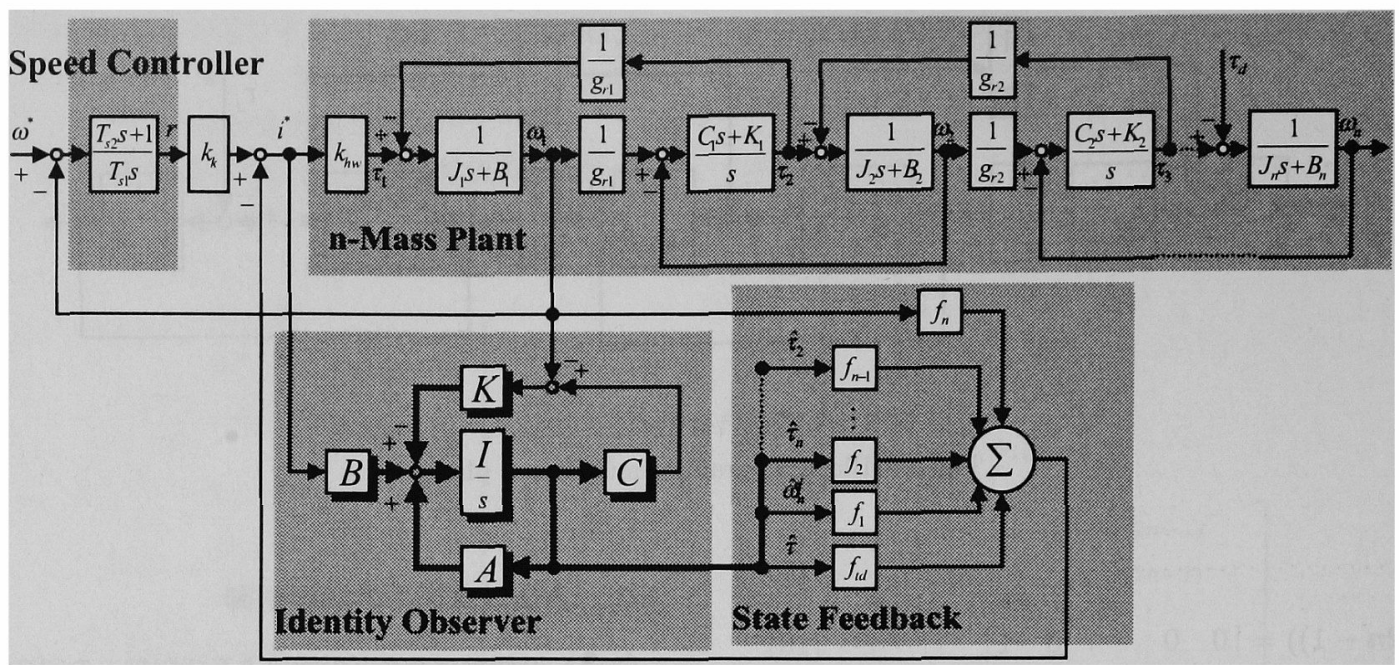

図 3 提案する多慣性速度制御系

Fig. 3. Proposed control system for multi-mass plant.

$K_{k}=\frac{\omega_{k 1}^{2}}{\omega_{r 1}^{2}} \cdot \frac{\omega_{k 2}^{2}}{\omega_{r 2}^{2}} \cdots \cdots \frac{\omega_{k(n-1)}^{2}}{\omega_{r(n-1)}^{2}}$

また, $\omega_{k i}, \zeta_{k i}$ は補償後の共振角周波数及び減衰定数であり, 任意に設定できるパラメータである。このとき，次のパラ メータを振動抑制用のパラメータとして設定する。

(1) $\zeta_{k i}$ (減衰係数)

（2） $\frac{\left.\omega_{k i} \text { (共振角周波数 }\right)}{\left.\omega_{a i} \text { (反共振角周波数 }\right)}=R_{i}$ (共振比)

ここで, 多慣性負荷系の周波数特性において, 新設プラン トの計画段階で, 所望の反共振比が得られなければ, 制御 対象のギア比や軸のバネ定数などにより反共振角周波数を 調整することが制振の観点からは好ましい。

\section{3 慣性負荷系による設計例}

具体例として, 表 1 のパラメータからなる 3 慣性負荷 系を制御対象とする。電動機側に対する負荷側の慣性比は $J_{3} / g_{1}^{2} g_{2}^{2} J_{1}=0.54$ である。以下, 2 慣性負荷系の場合 ${ }^{(8)}$ にならって説明する。

\section{$\langle\mathbf{4} \cdot \mathbf{1}\rangle$ 設計手順}

$\langle\mathbf{4} \cdot \mathbf{1} \cdot \mathbf{1}\rangle$ 速度制御器の設計 速度制御系のカットオ フ周波数 $\omega_{c s}$ を負荷系が剛体として設定する。ここでは, $\omega_{c s}<\omega_{a 1}(22.7[\mathrm{rad} / \mathrm{sec}])$ という制約を考慮して, $\omega_{c s}=$ $10[\mathrm{rad} / \mathrm{sec}]$ となる $P I$ 速度制御器を設計する。

$\langle\mathbf{4} \cdot \mathbf{1} \cdot \mathbf{2}\rangle$ 状態フィードバック係数の設計

（1） $\zeta_{k i}$ の設定 制御対象である 3 慣性負荷系の共振 比は (2) 式よ $\eta \omega_{r 1} / \omega_{a 1}=1.27, \omega_{r 2} / \omega_{a 2}=1.21$, $\omega_{a 2} / \omega_{a 1}=2.35$ である。ここでは, 2 次の振動モー ドまでしかないため, 1 次振動モードのみが $R$ の制約 を受ける。これらを前提に, 試行錯誤の簡単化のため 提案法においては, $R_{1}=R_{2}=1.27, \zeta_{k 1}=\zeta_{k 2}=\zeta$ と固定し, $\zeta$ を変化させた場合の時間応答および $P I$
表 13 慣性負荷系の各パラメータ

Table 1. Parameters of three-mass plant.

\begin{tabular}{|c|c|c|}
\hline$g_{r 1}$ & gear ratio & 2 \\
\hline$g_{r 2}$ & gear ratio & 2 \\
\hline$k_{h w}$ & transfer coefficient & $200[\mathrm{Nm} / \mathrm{rad}]$ \\
\hline$C_{1}$ & shaft stiffness & $1.40 \times 10^{-3}[\mathrm{Nm} / \mathrm{rad}]$ \\
\hline$C_{2}$ & shaft stiffness & $1.60 \times 10^{-2}[\mathrm{Nm} / \mathrm{rad}]$ \\
\hline$K_{1}$ & damping coefficient & $8.00[\mathrm{Nm} / \mathrm{rad} / \mathrm{s}]$ \\
\hline$K_{2}$ & damping coefficient & $12.0[\mathrm{Nm} / \mathrm{rad} / \mathrm{s}]$ \\
\hline$J_{1}$ & motor inertia & $2.06 \times 10^{-3}\left[\mathrm{~kg} \cdot \mathrm{m}^{2}\right]$ \\
\hline$J_{2}$ & load inertia & $4.28 \times 10^{-3}\left[\mathrm{~kg} \cdot \mathrm{m}^{2}\right]$ \\
\hline$J_{3}$ & load inertia & $1.54 \times 10^{-2}\left[\mathrm{~kg} \cdot \mathrm{m}^{2}\right]$ \\
\hline$B_{1}$ & coefficient of motor viscosity & $8.09 \times 10^{-4}[\mathrm{Nm} / \mathrm{rad} / \mathrm{s}]$ \\
\hline$B_{2}$ & coefficient of load viscosity & $5.00 \times 10^{-5}[\mathrm{Nm} / \mathrm{rad} / \mathrm{s}]$ \\
\hline$B_{3}$ & coefficient of load viscosity & $1.65 \times 10^{-3}[\mathrm{Nm} / \mathrm{rad} / \mathrm{s}]$ \\
\hline
\end{tabular}

補償による時間応答を図 4 に示す。らが大きくなるに つれて目標值応答時, トルク外乱応答時の振動が抑 制されているが, 目標值応答時のオーバーシュートが 大きくなってしまう。ここでは $P I$ 補償に比べてオー バーシュートが大きくならないように， $\zeta=0.34$ と 設定した。

（2） $R$ の設定 提案法において $\zeta=0.34$ と固定し, $R_{1}, R_{2}$ を変化させた場合の時間応答および $P I$ 補償 のみによる時間応答を図 5 に示す。ここでもらと同様 に, $R_{1}=R_{2}=R$ とした。 $R$ は反共振比以下にな るように $R<\omega_{a 2} / \omega_{a 1}=2.35$ とする。目標值応答 特性においては, $R=1.33$ 以上にしても大きな差は 現れない。トルク外乱応答特性においては $R=1.33$ 以上で特性の劣化が現れる。トルク外乱応答で良い 特性が得られるように, ここでは $R=1.33$ と設定 する。 


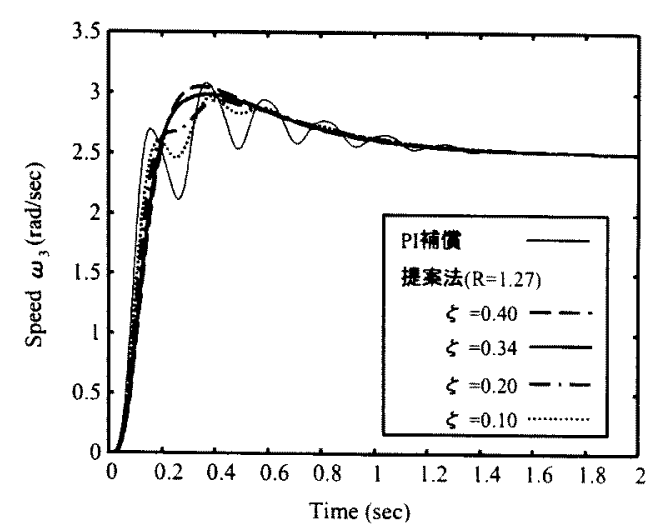

(a) 目標值底答

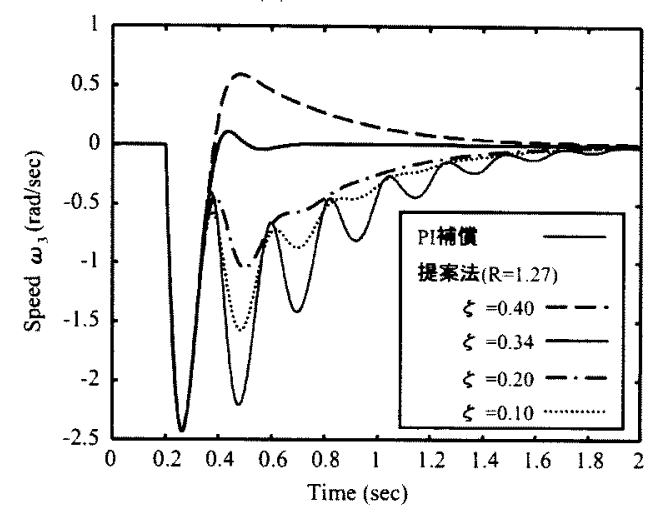

(b) 外乱応答

図4らを変化させたときのシミュレーション結果

Fig. 4. Simulation results for different $\zeta$.

なお，以上の $\zeta, R の$ 設定で設計仕様を満たさない場合に は，再度 (1)，(2)の設定過程を繰り返す。

設計された系の周波数特性を図 6に示す。共振比と減衰 定数を設定することにより，共振角周波数の特性が滑らか に改善されていることがわかる。

〈4・1・3 状態推定オブザーバの設計 2 慣性負荷系の 場合と同様に, 多慣性負荷系においても状態推定オブザ一 バの設計にあたっては，同一次元オブザーバを用いた。才 ブザーバの極 $\omega_{o}$ の設計については $\omega_{k 1}(70.8[\mathrm{rad} / \mathrm{sec}])<\omega_{o}$ を考慮し，実際の状態量をフィードバックした場合と比較 しその特性が劣化しないように，またノイズや高次の振動 モードの影響をうけないようにー75の 6 重根とした。設計 法については，例えば文献 [9]を参照されたい。

$\langle 4 \cdot 2\rangle$ 共振比及び速度制御系のカットオフ周波数に対 する設定自由度振動抑制効果の観点からは, 減衰係数 $\zeta_{k i}$ ，共振比 $R_{i}$ を大きくすることが望ましいが， $R_{i}$ を大き くした場合にはそれに伴い極配置が $s$ 平面上で左側入移動 していく。その結果， $R_{i}$ は DSPの演算速度及びサンプリ ング時間や電流許容値により制限を受ける。また $R_{i}$ は, 各 振動モードに拟いて反共振比以下となるように設定する必 要がある。

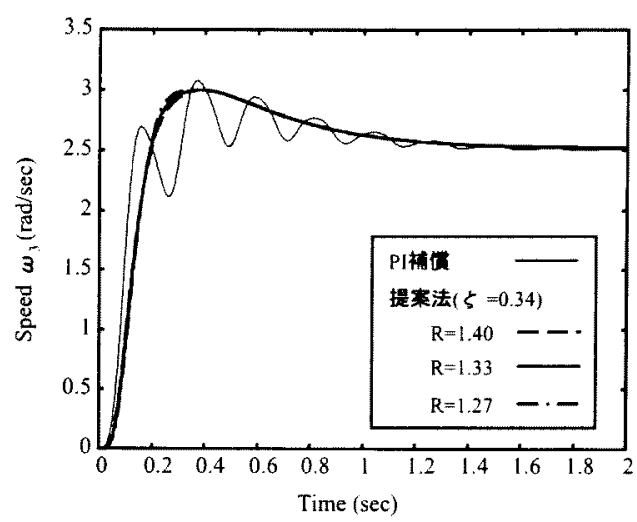

(a) 目標傎応答

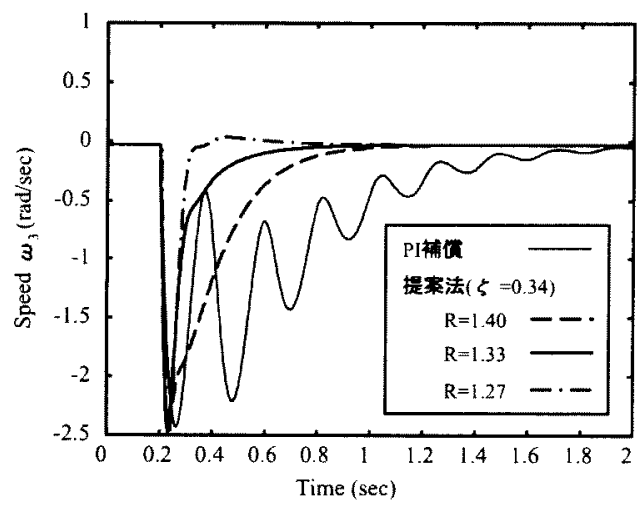

(b) 外乱応答

図 5 Rを変化させたときのシミュレーション 結果

Fig. 5. Simulation results for different $R$.

速度制御系のカットオフ周波数 $\omega_{c s}$ の設計の自由度に関し ては，2慣性負荷系と同様の制約を受ける。また, 慣性比 は 1 以下の場合にも，制振は可能である。

\section{5. 実験}

実験装置の構成は 2 慣性負荷系の実験に用いた装置 ${ }^{(8)}$ と 同様で，図7に示す。本装置は元来電動機ーギア間がリジッ トなベルトで接続された 2 慣性負荷系の機構であった。今 回フレキシブルなベルトを多数製作し，リジットなベルト をこのフレキシブルベルトに置き換え，さらに慣性モーメ ントの調整で, 所望の 3 慣性負荷系の機構を実現した。

$P I$ 補償のみの場合上提案法の場合の応答特性を図 8 に示 す。提案法の場合，速度指令，トルク外乱どちらに対しても 振動することなく，良好な特性が得られていることがわか る。次に, 負荷慣性 $J_{3} か ゙-30[\%]$ 変動した場合の奏騒結果を 図 9に示す。提案する補償法の場合, 負荷慣性 $J_{3}$ の-30[\%] の変動に対しても振動することなく，良好な特性が得られ ていることがわかる。

\section{6. あとがき}

本論文では，多慣性負荷系の特性を示し，筆者らが 2 慣 


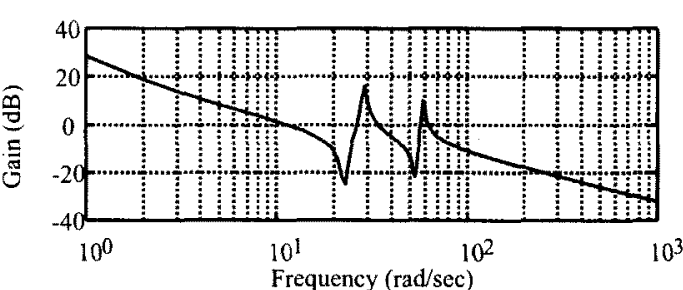

(a) PI 補裳法

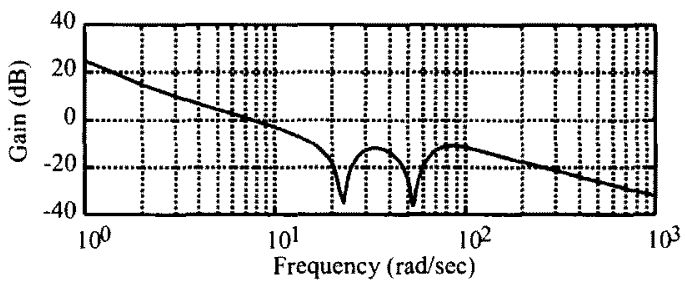

(b) 提案する補憆法

図 6 周波数応答 $\left(\omega_{1} / \omega^{*}\right)$

Fig. 6. Bode diagram from $\omega^{*}$ to $\omega_{1}$.

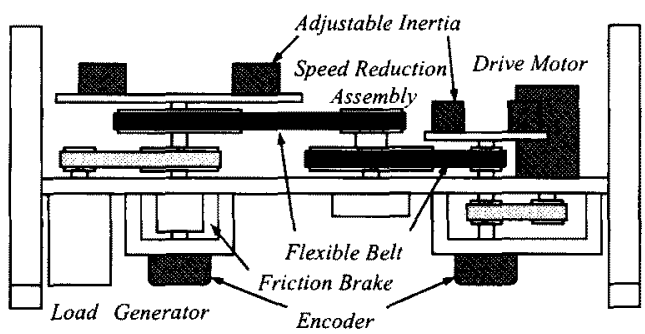

図 73 慣性負荷系実験装置の概要図

Fig. 7. Experimental setup for three-mass plant.

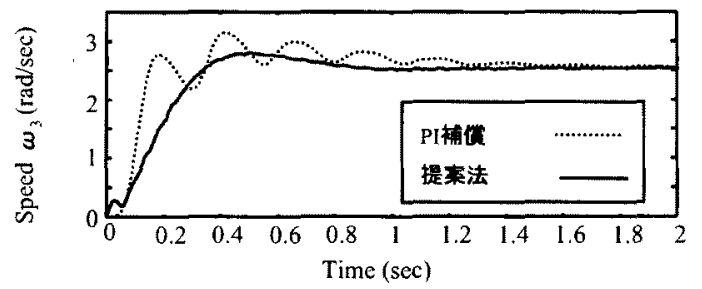

(a) 目標値応答

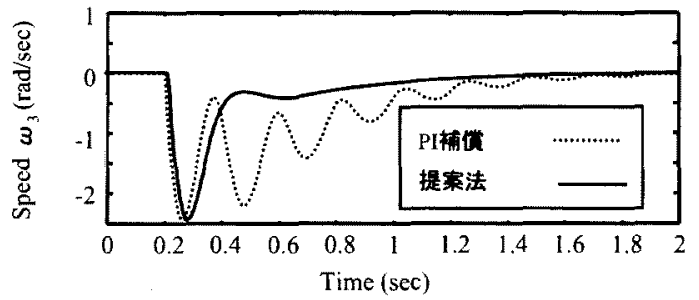

(b) トルク外乱地答

図 8 実験結果

Fig. 8. Experimental results.

性負荷系に対して適用した 2 可変パラメー夕による制振手 法を多慣性負荷系に適用する上での相違点を明らかにした。

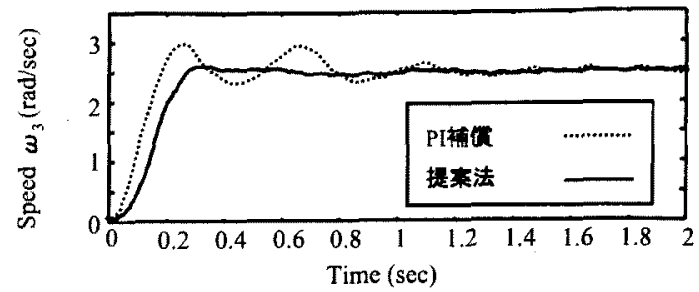

(a) 目標值底答

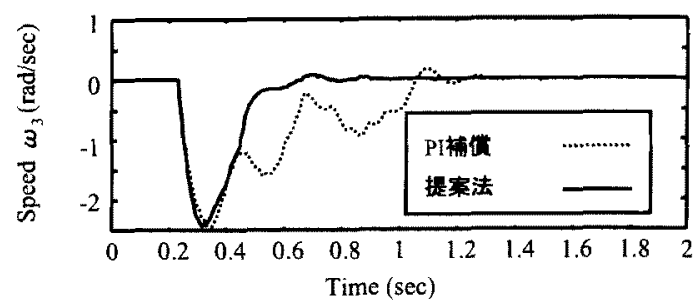

(b) トルク外乱㐫答

図 9 パラメー夕変動に対する奏験結果

Fig. 9. Experimental results for parameter variations.

多慣性負荷系への具体的な設計手順として，3慣性負荷系 に対する設計例を示した。シミュレーションと実験により 提案法の有効性を検証した。

主な結論は，以下のとおりである。

（1）制御対象のみに状態フィードバック補償を施すの で, 状態フィードバック係数の設計とは独立に速度 制御器を設計できた。

(2) 速度制御器は構成が簡単な $P I$ 速度制御器でよく, 負荷系を風体系と考えて設計できるため設計指針が 明解で，設計が容易であった。

（3）慣性比が 1 以下の場合（本論文では 0.54)でも軸ね じれ振動を抑制できることを確認した。

（4）負荷慣性 $J_{3}$ の-30[\%]の変動に対しても振動抑制 効果は失われなかった。

(平成 11 年 1 月 4 日受付, 同 11 年 3 月 29 日再受付)

\section{文献}

（1）松井，堀：「モータコントロールの新しい技術」，電学論 D, Vol 113, No. 10, pp. 1122-1137 (1993)

（2）結战，村上，大西:「共振比制御红上る 2 慣性共振系の振動抑制制 御」，電学論 D, Vol. 113, No. 10, pp. 1162-1169 (1993)

（3）誳:〔2惯性共振系の新しい制御法と最近の動向」，SICE口バスト 制御研究会凟料, pp. 1A1-1A6 (1995)

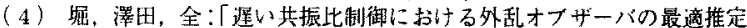
速度について」，電学諭 D, Vol. 117, No. 1，pp. 50-56 (1997)

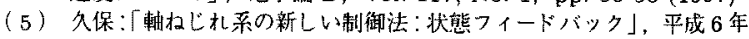
電気学会産業応用部門全国大会諈演論文集, S. 12-5，pp. S.319-322

（6）杉本，森本，武田，平紗:「状態フィードバックによる軸妃じり振動

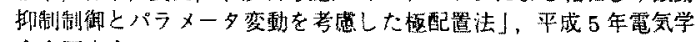
会全国大会，No. $671 ，$ p. 6-82

（7）磯貝，神山：「状態フィードバック補償を用いた 2 可変パラメータ

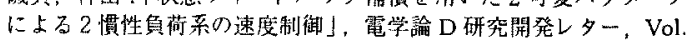
115, No. 8, pp. 1072-1073 (1995)

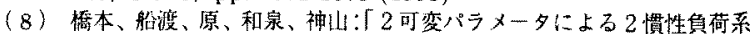
门振動邱制制御」，䉓学諭 D, Vol. 118-D, No. 10, pp. 1172-1176 (1998) 
（9）船渡，山本，橋本，神山：「2 可変パラメータによる多惯性負街系 の制振制御」，電学論 D 研究開発レター，Vol. 118，No. 11，pp 1334-1335 (1998)

（10）小鄉，美多:「システム制御理論人門」，実教出版株式会社 (1979)

（11）吉川，井村：「現代制御論」，昭晃堂 (1994)

（12）磯貝，野口，船渡，神山：「2 可変パラメータによる 3 慣性負荷系 の制振制御」，電気学会金属産業・産業電力電気応用合同研究会, IEA-95-15, pp. 77-84 (1995)

船渡寞人（正員） 1964 年 2 月 26 日生。1989 年 3 月横浜

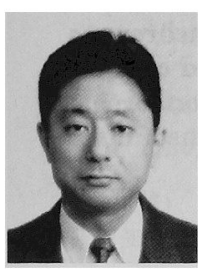
国立大学大学院工学研究科電子情報工学専攻博士 前期課程修了。同年 4 月東京電力株式会社入社。 1991 年 7 月同社退社。同年 8 月加 1992 年 3 月 まで横浜国立大学大学院研究生。1995 年 3 月横 浜国立大学大学院工学研究科電子情報工学専攻博 士後期課程修了。同年 4 月宇都宮大学工学部電気 電子工学科助手, 現在に至る。主として, パワー エレクトロニクスの電力系統への応用, モーションコントロール, 制 御応用, パワーエレクトロニクス回路に関寸る研究に従事。博士 (工 学)。1994 年度, 1996 年度電気学会論文発表賞受賞。計測自動制御学 会, IEEE 会員。

山本磨人（正員） 1975 年 3 月 14 日生。1997年 3 月宇都宮

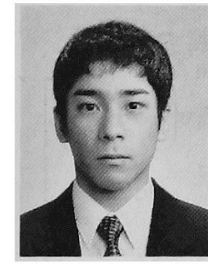
大学工学部電気電子工学科卒業。1 999 年 3 月宇 都宮大学大学院工学研究科電気電子工学専攻博士 前期課程修了。同年 4 月キャノン株式会社入社, 現在に至る。在学中, パワーエレクトロニクス及 びモータコントロールに関する研究に従事。

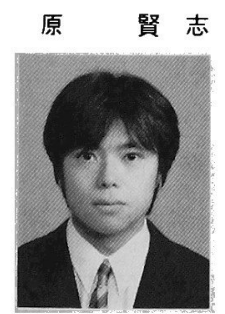

(学生員) 1973 年 10 月 24 日生。1998 年 3 月宇 都宮大学大学院工学研究科博士前期課程電気電子 工学専攻修了。同年 4 月宇都宮大学大学院工学研 究科博士後期課程物性工学専攻入学, 現在に至る。 パワーエレクトロニクス及びモータコントロール に関する研究に従事。

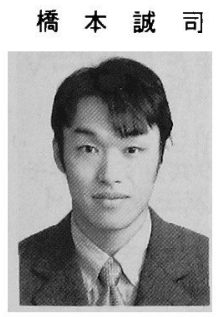

（正員） 1971 年 12 月 19 日生。1996 年 3 月宇 都宮大学大学院工学研究科博士前期課程電気電子 工学尃攻修了。1999 年 3 月宇都宮大学大学院工 学研究科博士後期課程物性工学専攻修了。同年 5 月宇都宮大学大学院工学研究科+テライト・ベン チャー・ビジネス・ラボラトリー研究員, 現在に 至る。ロバスト制御，システム同定のモーション コントロール，構造体の制振制御分野への応用研 究に従事。博士 (工学)。1995 年電気学会論文発表賞受賞。電気学会, 計測自動制御学会, 日本機械学会, IEEE 会員。
神山健三（正員）1936 年 3 月 12 日生。1961年 3 月早稲 田大学大学院修士課程修了。同年 4 月 (秼) 日立 製作所入社，モータドライブの開発設計に従事， 1991 年 3 月退社。1991 年 4 月宇都宮大学工学部 教授, 現在に至る。工学博士。パワーエレクトロ ニクス，モータドライブ及びアドバンスト制御の 研究と教育に従事。電気学会, 計測自動制御学会, IEEE などの会員。 